\title{
Implementasi AHP Sistem Penunjang Keputusan Promosi Jabatan di Universitas Sam Ratulangi
}

\author{
Martina K. E. T. Dundu, Steven R. Sentinuwo, Agustinus Jacobus \\ Teknik Informatika Universitas Sam Ratulangi \\ 110216125@student.unsrat.ac.id , steven@unsrat.ac.id, a.jacobus@unsrat.ac.id
}

\begin{abstract}
Abstrak - Pegawai adalah aset yang sangat penting dalam suatu organisasi tak terkecuali di Unsrat. Guna memberi penghargaan dan sebagai motivasi kepada pegawai yang ada, maka dibuatlah sebuah sistem penunjang pengambilan keputusan sebagai masukan bagi pimpinan Unsrat untuk promosi jabatan. Sistem ini dibuat menggunakan metode perhitungan AHP(Analytical Hierarchy Process). AHP menghasilkan sebuah rangking yang didapat dari membandingkan setiap kriteria dan juga alternatif dalam hal ini bakal calon yang akan diberikan promosi jabatan. Sistem ini memberikan laporan akhir bakal calon yang paling memenuhi persyaratan yang ada. Perhitungan yang dilakukan sistem ini lebih efisien dari cara manual. Sistem ini telah diuji dengan beberapa jenis pengujian.
\end{abstract}

Kata kunci : Promosi Jabatan, Unsrat, Sistem Penunjang Keputusan, $\boldsymbol{A H P}$.

\section{PENDAHULUAN}

Pegawai merupakan aset yang sangat penting bagi sebuah organisasi. Universitas Sam Ratulangi(Unsrat) sebagai universitas negeri yang paling besar di Manado, pastinya memiliki pegawai yang sangat banyak. Diantara banyaknya pegawai yang ada, jika terjadi sebuah kekosongan dalam suatu jabatan maka akan sangat sulit untuk memilih pegawai yang akan mengisinya. Promosi jabatan merupakan salah satu sarana penghargaan ataupun memberikan motivasi untuk para pegawai. Penilaian prestasi kerja terhadap pegawai merupakan tolak ukur utama dalam membangun sumber daya manusia. Pegawai yang memiliki rekam jejak baik dan mau berkembang patut diberikan promosi jabatan. Motivasi dapat digunakan untuk mendorong pegawai lebih baik atau lebih bersemangat melakukan suatu pekerjaan dalam lingkungan organisasi. Dengan demikian maka penilai kerja yang mengarah pada promosi jabatan harus dilakukan dengan efektif agar dapat diterima semua pihak. Promosi jabatan dilaksanakan untuk mengoptimalkan sumber daya manusia yang dimiliki organisasi, selain itu promosi jabatan bertujuan untuk meregenerasi sumber daya manusia dalam organisasi demi kelangsungan organisasi tersebut.

Banyaknya kriteria dan bakal calon yang akan diberikan promosi jabatan membuat pengambilan keputusan masalah ini menjadi rumit dan jika menggunakan perhitungan manual akan memerlukan waktu yang lama, belum adil dan lain sebagainya.

Karena itu dibuatlah sebuah sistem yang dijadikan penunjang dalam pengambilan keputusan promosi jabatan sebagai masukan bagi pimpinan Uns rat.

\section{LANDASAN TEORI}

\section{A. Promosi Jabatan}

Menurut Hasibuan dalam Pasaribu Eva Solita dan Iskandar (2015), Promosi Jabatan adalah perpindahan yang memperbesar authority dan responsibility karyawan ke jabatan yang lebih tinggi didalam suatu organisasi sehingga kewajiban, hak, status dan penghasilan semakin besar.

Tujuan untuk dilaksanakannya promosi jabatan dalam suatu organisasi yaitu :

- Untuk memberikan pengakuan, jabatan, dan imbalan jasa yang semakin besar kepada pegawai yang berprestasi kerja tinggi.

- Dapat menimbulkan kepuasan dan kebanggaan pribadi, meningkatnya status sosial dan penghasilan.

- Untuk merangsang pegawai/karyawan untuk lebih gairah bekerja, berdisiplin tinggi, dan memperbesar kinerjanya.

- Untuk menjamin stabilitas kepegawaian.

- Memperbaiki status pegawai/karyawan.

Maka dari itu penilaian terhadap promosi yang akan dilakukan haruslah dilakukan dengan efektif agar dapat diterima semua pihak tanpa ada yang merasa dirugikan.

Karena Unsrat merupakan perguruan tinggi negeri maka pegawai yang akan diberikan promosi jabatan memiliki syarat mutlak yaitu berstatus Aparatur Sipil Negara(ASN). Dan berikut ini adalah bahan pertimbangan yang dijadikan syarat ataupun instruksi untuk melakukan promosi jabatan yang telah diatur oleh pemerintah yaitu:

- Undang-undang No. 5 tahun 2014, tentang Aparatur Sipil Negara

- Keputusan Kepala Badan Kepegawaian Negara No. 13 tahun 2002, tentang Ketentuan Pelaksanaan Peraturan Peraturan Pemerintah No. 100 tahun 2000 tentang Pengangkatan Pegawai Negeri Sipil dalam Jabatan Struktural 
- Surat Edaran Menpan No. 16 tahun 2012, Tata Cara Pengisian Jabatan Struktural yang Lowong secara Terbuka di Lingkungan Instansi Pemerintah.

\section{B. Analytical Hierarchy Process}

Analytical Hierarchy Process (AHP) adalah sebuah metode yang bertujuan untuk optimalisasi pengambilan sebuah keputusan. AHP dikembangkan oleh Dr. Thomas L. Saaty untuk mengorganisasikan informasi dan judgement dalam memilih alternatif yang paling disukai. Pengambilan keputusan dari persoalan yang rumit dapat disederhanakan dan dipercepat.(Marimin, 2004)

Prinsip kerja AHP adalah sebagai berikut:

- Penyusunan Hierarki.

- Matriks Komparasi/Perbandingan berpasangan (Pair Wise Comparison).

- Penilaian Kriteria dan Alternatif.

- Penentuan Prioritas

- Konsistensi Logis

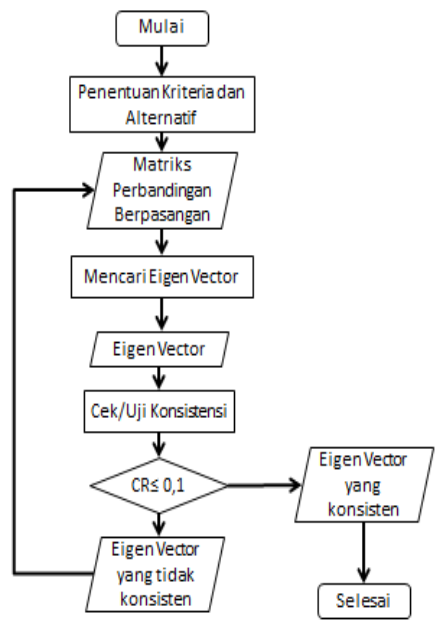

Gambar 1. Langkah-langkah Perhitungan AHP

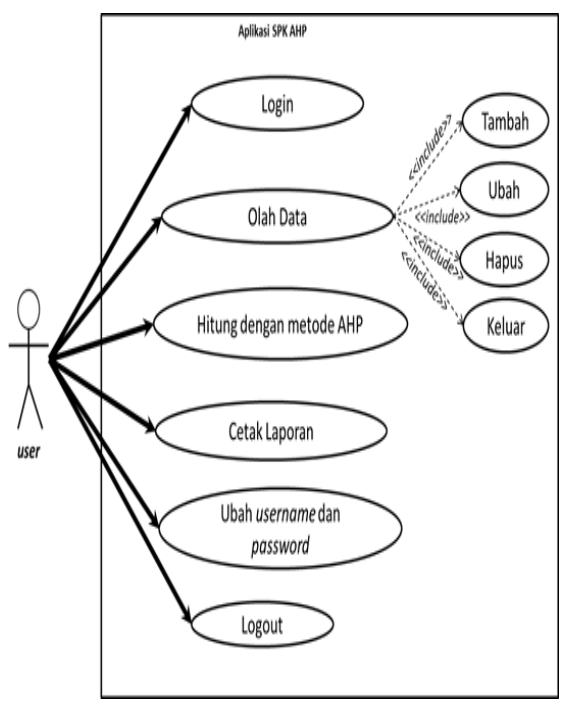

Gambar 2. Use Case Diagram
Dalam metode $A H P$ dilakukan perhitungan-perhitungan sebagaimana yang tergambar dalam flowchart pada Gambar 1 . Pertama, kita menentukan kriteria dan alternatif apa saja yang akan dipakai. Kemudian, membandingkan kriteria dan alternatif dengan cara membuat matriks perbandingan berpasangan. Dari hasil perbandingan itu didapatlah eigen vector yang harus di uji apakah sudah memunuhi syarat yaitu $C R \leq 0,1$. Ketika hasil pengujian menyatakan $C R \leq 0,1$ maka proses tersebut telah selesai. Jika tidak sesuai dengan syarat maka diarahkan untuk kembali pada proses perbandingan berpasangan.

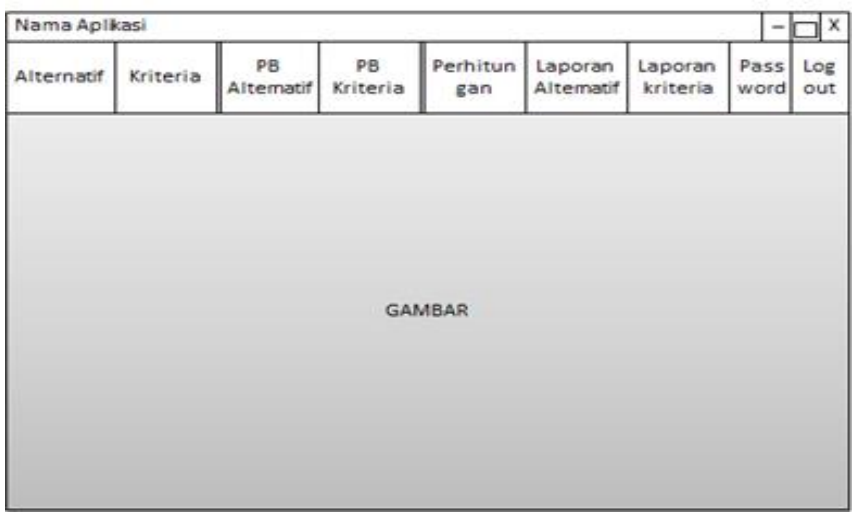

Gambar 3. Perancangan Cepat Antar Muka Halaman Utama

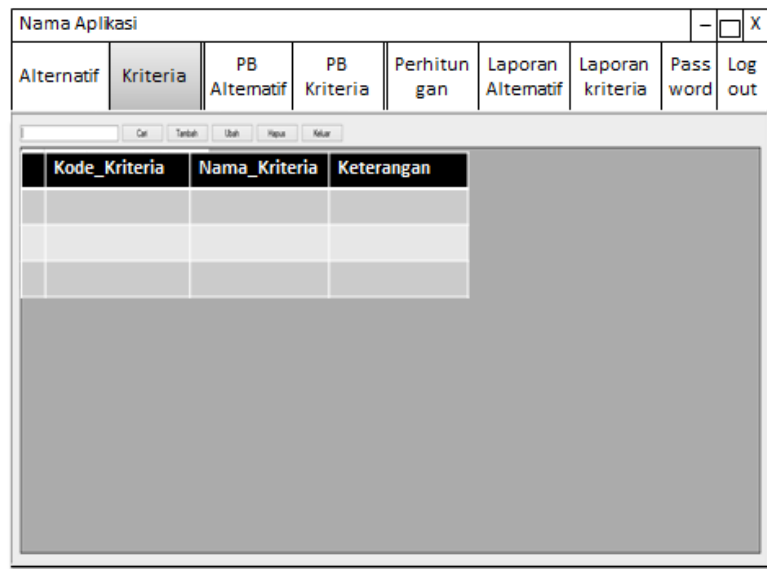

Gambar 4. Perancangan Cepat Antar Muka Halaman Utama

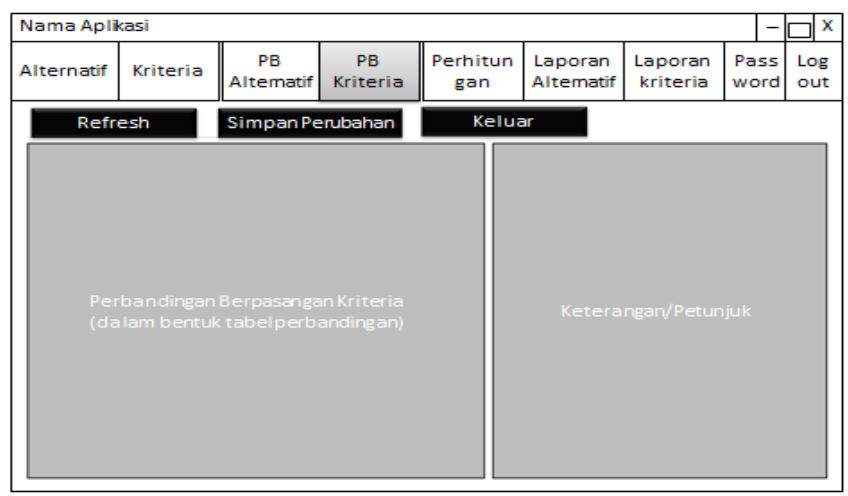

Gambar 5. Halaman PB Kriteria 


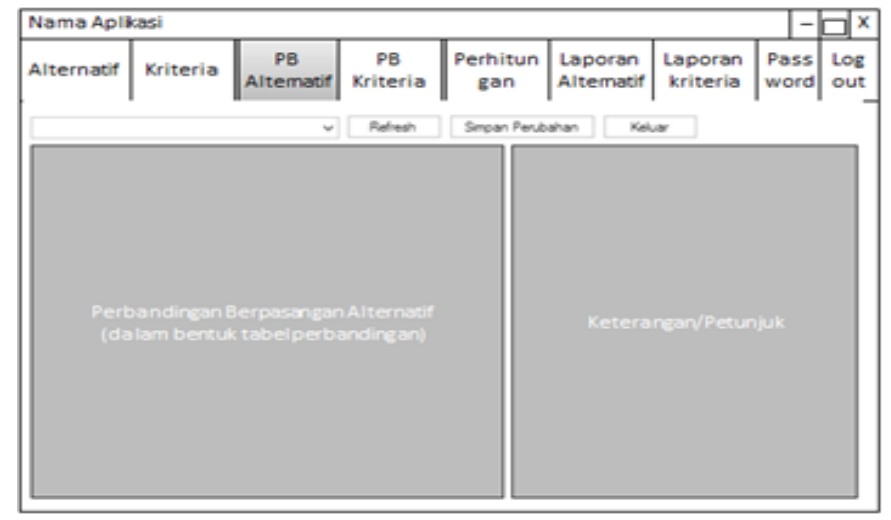

Gambar 6. Halaman PB Alternatif

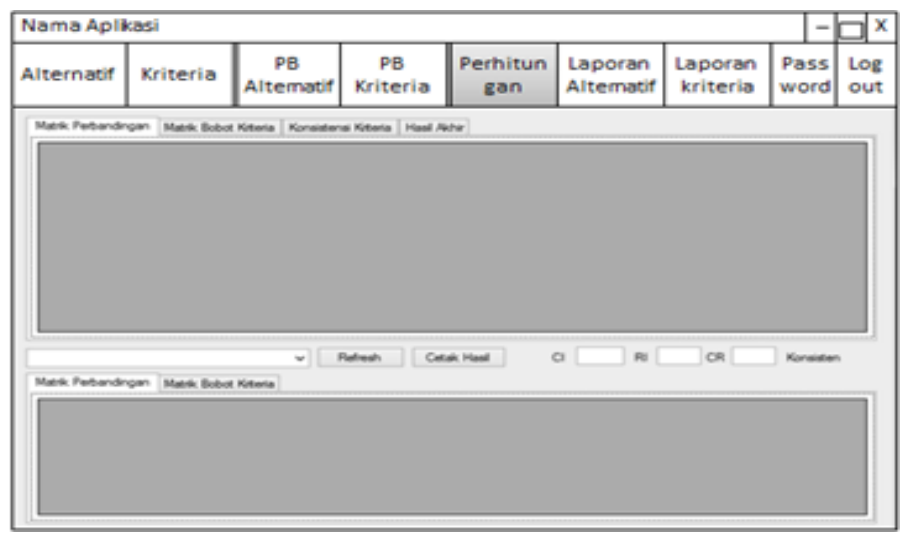

Gambar 7. Halaman Perhitungan

\section{METODOLOGI PENELITIAN}

Pada tahap ini peneliti menggunakan metode perhitungan AHP sedangkan untuk perancangan sistem menggunakan prototyping, dengan tahapan - tahapan yang digunakan yaitu:

- Pengumpulan kebutuhan/data yang dilakukan dengan cara studi literatur dan wawancara. Dari hasil wawancara dan studi literatur, dilakukanlah analisa data dan fitur yang akan digunakan.

- Perancangan cepat, proses ini dilakukan dengan cara membuat Unified Modeling Language(UML) dan perancangan antar muka. Perancangan cepat yang dibuat pada penelitian ini adalah use case diagram yang dapat dilihat pada Gambar 2. Untuk rancangan antar muka halaman utama seperti Gambar 3. Sedangkan untuk perancangan antar muka menu kriteria dapat dilihat pada Gambar 4. Antar muka untuk kriteria dan alternatif memiliki fitur yang sama. Gambar 5 merupakan rancangan tampilan dari menu PB Kriteria. Gambar 6 adalah rancangan untuk menu PB Alternatif yang dimana perbandingan berpasangan antar alternatif per kriteria yang ada. Kemudian rancangan antar muka menu perhitungan seperti yang terlihat pada Gambar 7.

- Prototyping, yang dimaksud adalah proses mulai membuat tampilan pada dan mengkodekan sistem pada aplikasi yang digunakan untuk membuat sistem dalam penelitian ini menggunakan Visual Studio.
- Pengujian dan evaluasi, langkah ini diperlukan untuk mencari kesalahan/kekurangan dalam proses pembuatan.

- Perbaikan, proses ini dilakukan setelah umpan balik dari pengujian dan evaluasi diberikan oleh pengguna.

\section{HASIL DAN PEMBAHASAN}

Data kriteria yang dipakai dalam penelitian ini berdasarkan hasil analisa data dari wawancara dan studi literatur adalah pendidikan, kepangkatan, prestasi kerja, kompetensi jabatan, kesehatan, diklat jabatan, yang terakhir komunikasi dan kerjasama. Sedangkan untuk fitur yang digunakan sesuai dengan yang ada pada tampilan.

Kriteria yang digunakan dalam penelitian ini sebagaimana yang dijelaskan diatas, kemudian dimasukkan dalam aplikasi yang dibuat sebagaimana pada Gambar 8.

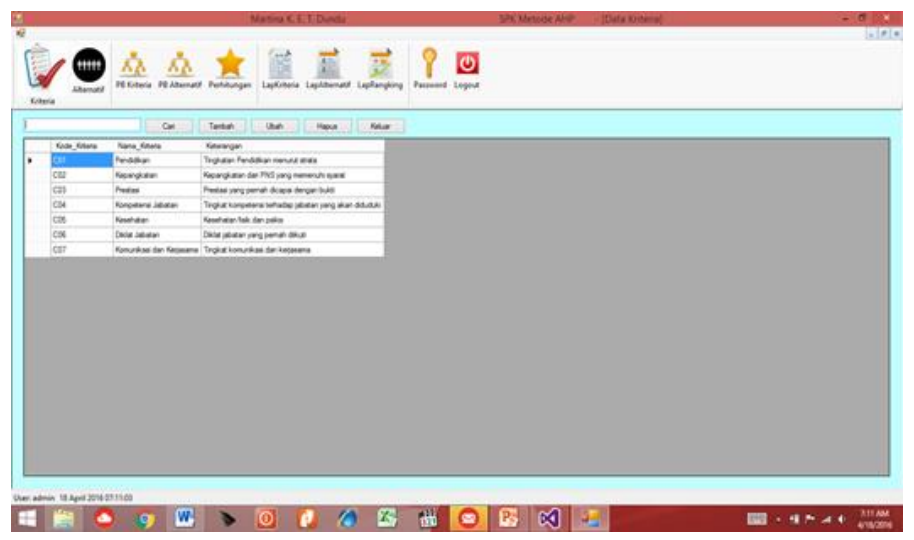

Gambar 8. Kriteria yang dipakai

Gambar 9 menjelaskan tentang data alternatif yang digunakan dalam penelitian ini.

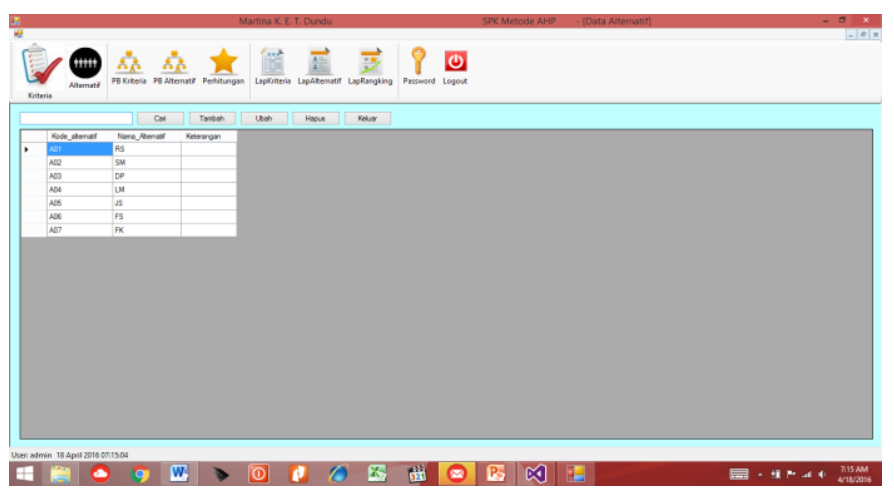

Gambar 9. Alternatif atau calon yang dipakai

Gambar 10 tentang perbandingan antar kriteria yang bertujuan untuk mendapatkan nilai eigen vector. 


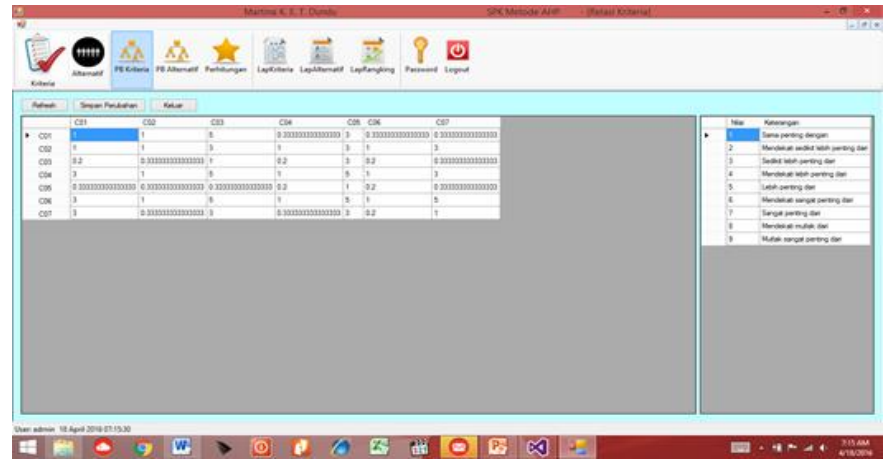

Gambar 10. Perbandingan Berpasangan Kriteria

Perbandingan Berpasangan Alternatif dilakukan untuk setiap kriteria dengan tujuan mendapatkan nilai eigen vector dari setiap alternatif pada setiap kriteria.Contohnya pada Gambar 11 dimana alternatif A01 memiliki pendidikan yang sama dengan alternatif A02, sama dengan alternatif A03, A05 dan A07, sedangkan alternatif A04 memiliki pendidikan sedikit lebih dari alternatif A01. Begitu juga pada Gambar 12 terlihat bahwa alternatif A01 memiliki kepangkatan sedikit lebih tinggi dibanding alternatif A03, A04, A05, A06 dan A07, namun mendekati sedikit lebih rendah dari alternatif A02. Gambar 13 terhadap kriteria prestasi dimana alternatif $\mathrm{A} 02$ prestasi yang lebih tinggi dari alternatif $\mathrm{A} 03, \mathrm{~A} 04, \mathrm{~A} 05$, A06 dan A07, namun sama dengan alternatif A01.

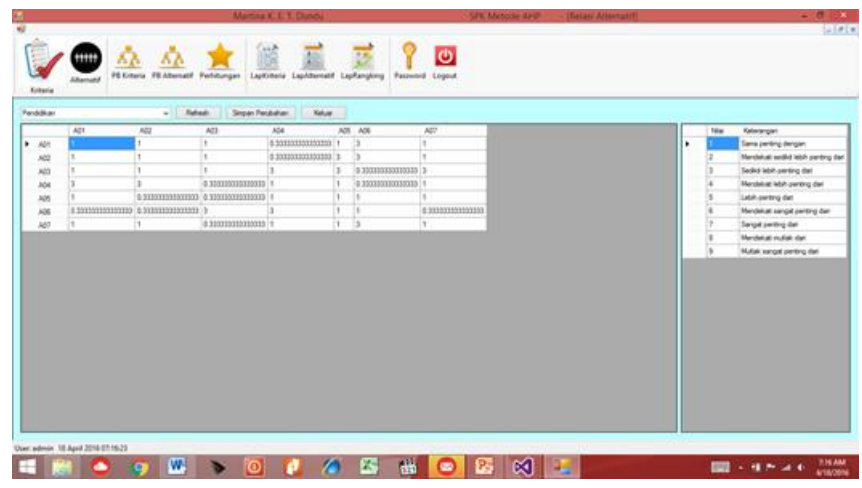

Gambar 11. Perbandingan Berpasangan Alternatif untuk kriteria Pendidikan

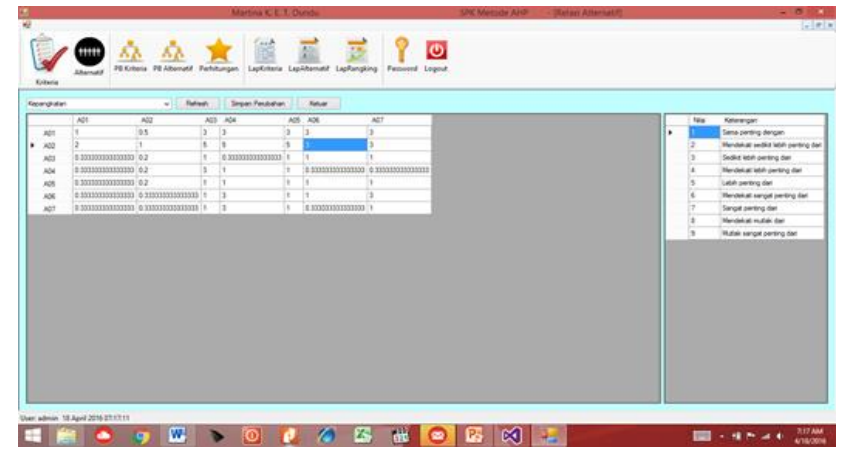

Gambar 12. Perbandingan Berpasangan Alternatif untuk kriteria Kepangkatan

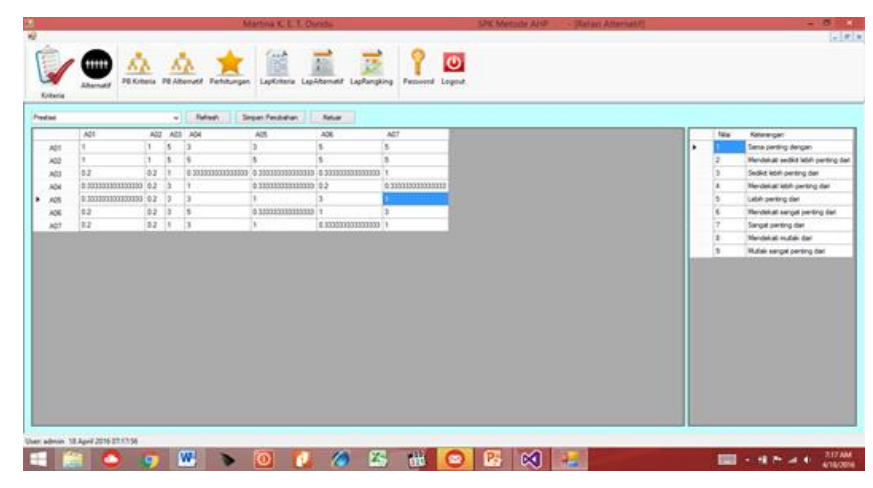

Gambar 13. Perbandingan Berpasangan Alternatif untuk kriteria Prestasi

Gambar 14 merupakan tampilan dari menu Perhitungan dimana dengan memilih menu tersebut akan langsung muncul hasil perhitungan yang memberikan nilai eigen value sehingga didapat skala prioritas atau urutan-urutan dari alternatif.

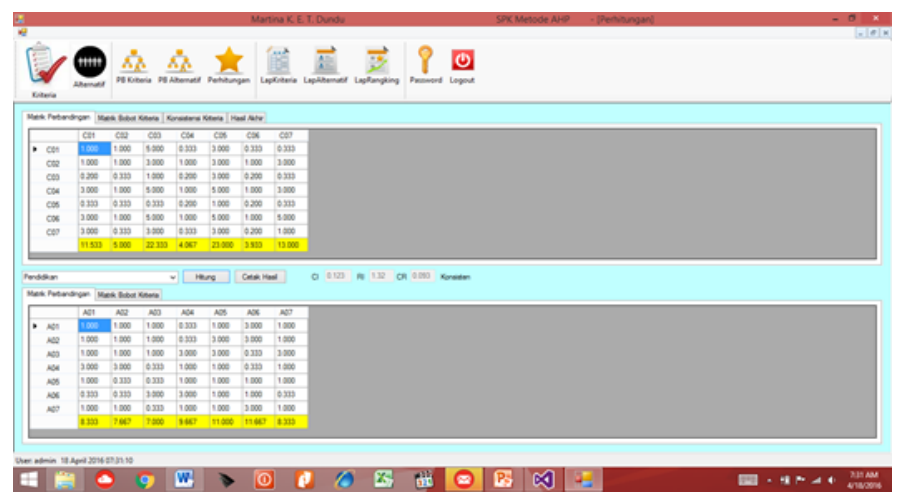

Gambar 14. Tampilan Perhitungan dengan Metode AHP

Dari Gambar 15, yang pertama harus dilihat adalah apakah perbandingan berpasangan sudah konsisten atau tidak. Hal ini dapat ditunjukkan dengan nilai Consistency Ratio $(C R)$. Jika CR > 0,1, maka perbandingan berpasangan harus dilakukan ulang hingga mendapatkan nilai $\leq 0$. Gambar ini pula merupakan hasil akhir dari perhitungan AHP yang ditandai dengan adanya rank. Dan alternatif yang mendapat nilai paling tinggi adalah alternatif yang paling direkomendasikan untuk diberi promosi jabatan.

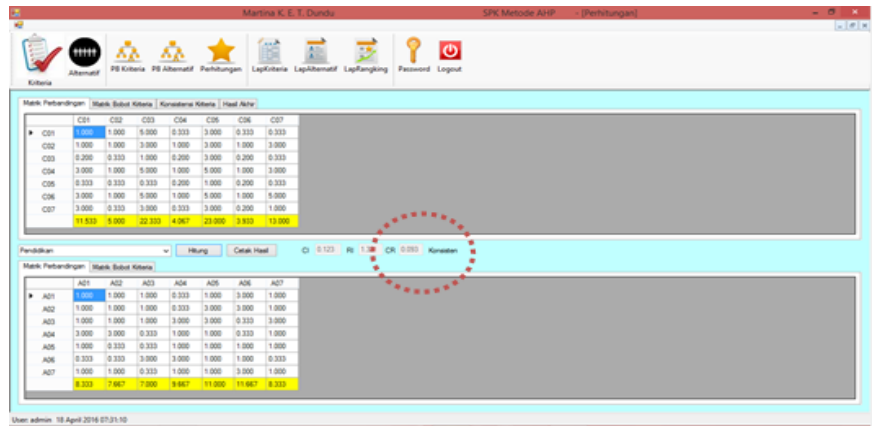

Gambar 15. CR dari Perbandingan Berpasangan 
Gambar 16 merupakan tampilan dari Laporan Rangking yang dimana laporan ini memiliki tampilan seperti surat dan dilengkapi dengan kepala surat yang berlambangkan universitas. Disini kita dapat mencetak maupun menyimpan laporan tersebut.

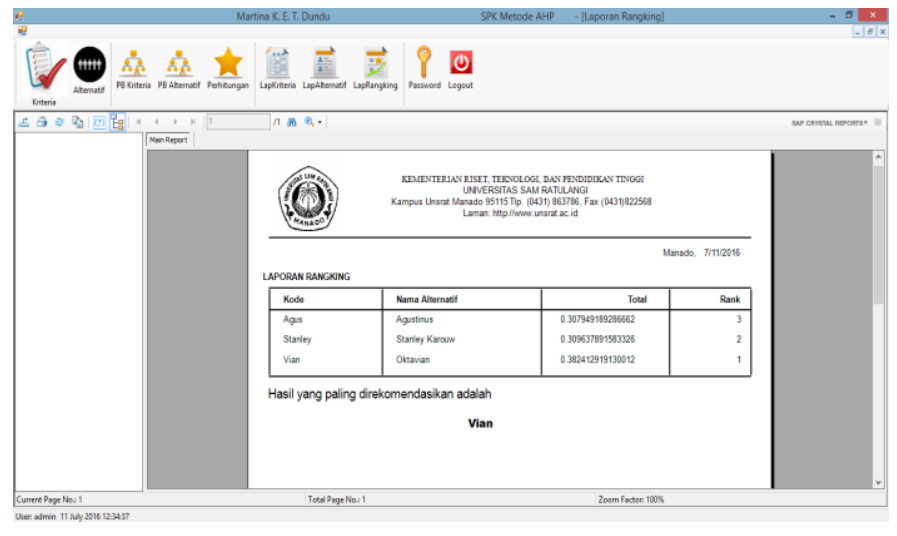

Gambar 16. Laporan Rangking

- Pengujian Sistem

Metode yang digunakan untuk menguji fungsi dan tampilan adalah black box dan contohnya seperti pada Tabel 1. Dalam proses pengujiannya untuk hasil akhir dari perhitungan yang dilakukan oleh aplikasi ini, diperlukan pengujian yang membuktikan bahwa hasilnya benar atau sesuai yaitu dengan cara membandingkan dengan hasil perhitungan manual $A H P$ yang dapat dilihat pada Tabel 2 dan Tabel 3. Pada Tabel 4, karena tidak ditemukan selisih, maka perhitungan dalam aplikasi dapat digunakan atau sama dengan perhitungan manual. Sedangkan untuk memenuhi permintaan pengguna dilakukan User Acceptance Testing (UAT) yang terdiri dari Tabel 4 uji alfa dan Tabel 5 uji beta.

TABEL 1. PENGUJIAN BLACK BOX

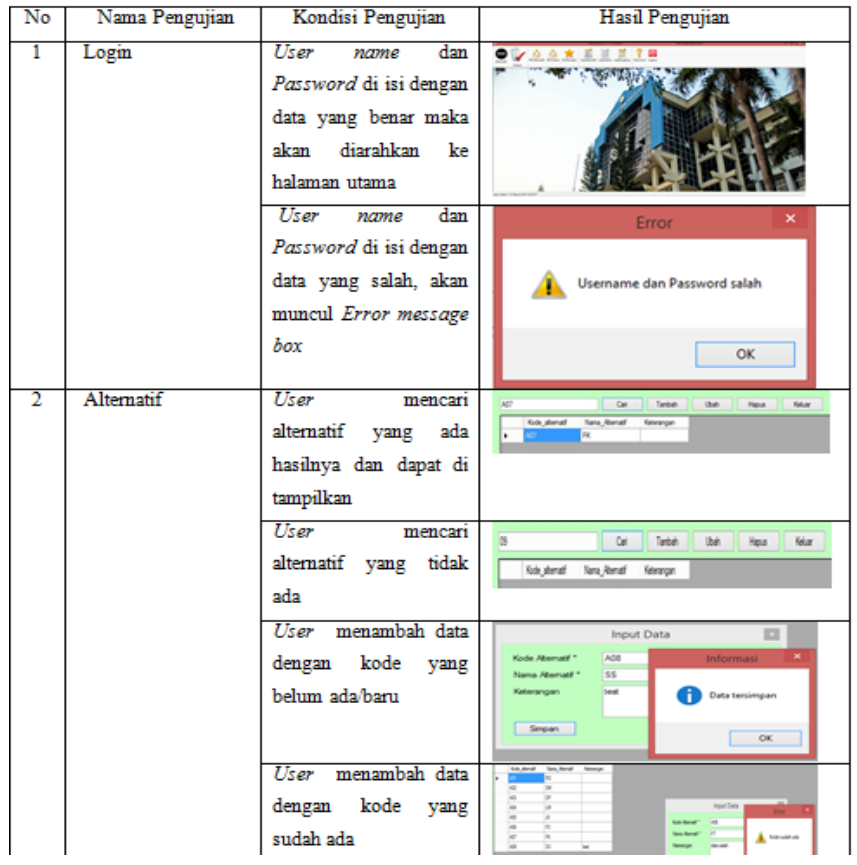

TABEL 2. HASIL PERHITUNGAN MANUAL

\begin{tabular}{|c|c|c|c|c|c|c|c|c|}
\hline 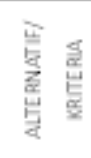 & $\begin{array}{l}\frac{c}{\bar{c}} \\
\frac{\bar{y}}{\mathrm{z}} \\
\mathrm{g} \\
\mathrm{g}\end{array}$ & 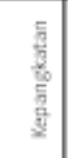 & '高 & 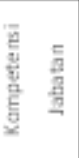 & 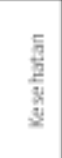 & $\begin{array}{l}\frac{5}{2} \\
\frac{7}{3} \\
\frac{3}{8} \\
\frac{8}{5}\end{array}$ & 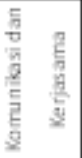 & $\frac{.}{\partial}$ \\
\hline sM & 0.154 & 0.338 & 0.317 & 0.358 & 0.210 & 0.158 & 0.300 & 0.264 \\
\hline 75 & 0.178 & 0.223 & 0.277 & 0.728 & 0.174 & 0.158 & 0.168 & 0.191 \\
\hline $\mathrm{FS}$ & 0.148 & 0.124 & 0.114 & 0.077 & 0.136 & 0.158 & 0.105 & 0.122 \\
\hline LM & 0.163 & 0.078 & 0.061 & 0.090 & 0.104 & 0.158 & 0.093 & 0.113 \\
\hline $\mathrm{FK}$ & 0.124 & 0.091 & 0.071 & 0.082 & 0.135 & 0.158 & 0.105 & 0.112 \\
\hline E & 0.087 & 0.075 & 0.116 & 0.077 & 0.135 & 0.158 & 0.142 & 0.111 \\
\hline$D P$ & 0.195 & 0.070 & 0.044 & 0.089 & 0.104 & 0.053 & 0.087 & 0.087 \\
\hline
\end{tabular}

TABEL 3. HASIL APLIKASI

\begin{tabular}{|c|c|c|c|c|c|c|c|c|}
\hline 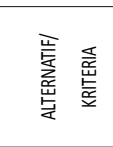 & 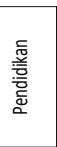 & 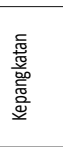 & $\begin{array}{l}\text { 要 } \\
\text { 离 }\end{array}$ & 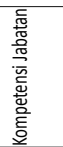 & 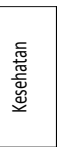 & 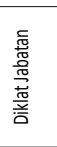 & 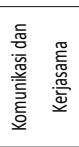 & 总 \\
\hline $\mathrm{AO2}-\mathrm{SM}$ & 0.154 & 0.338 & 0.317 & 0.358 & 0.21 & 0.158 & 0.3 & 0.264 \\
\hline A01 - RS & 0.128 & 0.223 & 0.277 & 0.228 & 0.174 & 0.158 & 0.168 & 0.191 \\
\hline A06 - FS & 0.148 & 0.124 & 0.114 & 0.077 & 0.136 & 0.158 & 0.105 & 0.122 \\
\hline A04 - LM & 0.163 & 0.078 & 0.061 & 0.09 & 0.104 & 0.158 & 0.093 & 0.113 \\
\hline AO7 - FK & 0.124 & 0.091 & 0.071 & 0.082 & 0.136 & 0.158 & 0.105 & 0.112 \\
\hline A05 - Js & 0.087 & 0.076 & 0.116 & 0.077 & 0.136 & 0.158 & 0.142 & 0.111 \\
\hline$A 03$ - DP & 0.195 & 0.07 & 0.044 & 0.089 & 0.104 & 0.053 & 0.087 & 0.087 \\
\hline
\end{tabular}

TABEL 4. PERBANDINGAN HASIL MANUAL DAN APLIKASI

\begin{tabular}{|c|c|c|c|}
\hline $\begin{array}{c}\text { ALTERNATIF/ } \\
\text { KRITERIA }\end{array}$ & Manual & Sistem & Selisih \\
\hline SM & 0.264 & 0.264 & 0.000 \\
\hline RS & 0.191 & 0.191 & 0.000 \\
\hline FS & 0.122 & 0.122 & 0.000 \\
\hline LM & 0.113 & 0.113 & 0.000 \\
\hline FK & 0.112 & 0.112 & 0.000 \\
\hline JS & 0.111 & 0.111 & 0.000 \\
\hline DP & 0.087 & 0.087 & 0.000 \\
\hline
\end{tabular}

TABEL 5. USER ACCEPTANCE TESTING, UJI ALFA PENELITIAN

\begin{tabular}{|c|c|c|c|c|c|}
\hline \multirow[b]{2}{*}{ No. } & \multirow[b]{2}{*}{ Jenis Uji } & \multicolumn{4}{|c|}{ Keterangan } \\
\hline & & Diterima & Tidak & Perbaikan & Catatan \\
\hline 1 & Easen & $\gamma$ & & & \\
\hline 2 & Link yeng putus & $\gamma$ & & & \\
\hline 3 & Goudy direction & $v$ & & & \\
\hline 4 & $\begin{array}{l}\text { Ui Nesin lebih } \\
\text { rendah }\end{array}$ & & $\gamma$ & & $\begin{array}{l}\text { Tidak ada hompular yang } \\
\text { spesifk aimplebih rendah }\end{array}$ \\
\hline
\end{tabular}

TABEL 6. USER ACCEPTANCE TESTING, UJI BETA PENELITIAN

\begin{tabular}{|c|c|c|c|c|c|}
\hline \multirow{2}{*}{ No } & \multirow{2}{*}{ toris $U_{j i}$} & \multirow{2}{*}{ Umpan Balik } & \multicolumn{3}{|c|}{ Ken we rangan } \\
\hline & & & Diterima & Purbaiki & Tanda tangan \\
\hline 1 & $\begin{array}{l}\text { Imbal soltwase } \\
\text { dan } \\
\text { morialiarken }\end{array}$ & 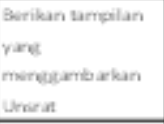 & $\checkmark$ & & \\
\hline 2 & 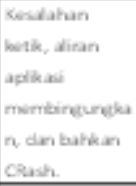 & 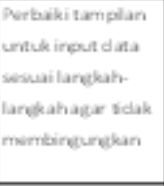 & $\checkmark$ & & \\
\hline 3 & Oulput & 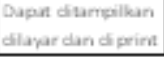 & $\checkmark$ & & \\
\hline
\end{tabular}


E-journal Teknik Informatika, Volume 7, No 2 (2016), ISSN : 2301-8364

- Perbaikan Prototype

Perbaikan prototype dilakukan dengan memperbaiki sesuai umpan balik dari user dan dapat diterima oleh user.

\section{PENUTUP}

\subsection{Kesimpulan}

Dari hasil penelitian ini didapatkan bahwa alternatif A02 yang adalah calon dengan skor tertinggi sehingga alternatif ini merupakan alternatif yang memiliki prioritas tertinggi dan paling pantas diberikan promosi jabatan. A01, A06, A04, A07, A05, dan A03 berturut-turut dalam prioritas. Hasil dari aplikasi ini sudah diuji dengan perhitungan manual dan tidak ditemukan selisih yang artinya sudah sesuai.

\subsection{Saran}

Metode AHP sangat disarankan untuk para pengambilan keputusan karena metode ini memberikan hasil terbaik yang sesuai dengan syarat yang ada melalui skala prioritas. Metode ini cocok untuk permasalah dengan multi kriteria dapat dibuat menggunakan bahasa pemrogrman apa saja.

\section{DAFTAR REFERENSI}

Adnan Khairil, dkk., 2013, Sistem Pendukung Keputusan Penentuan Pemberian Pinjaman Uang Dengan Metode AHP (Analytic Hierarchy Process) Di Koperasi Simpan Pinjam Eka Mulya, Jurnal Online ICT STMIK IKMI - Vol.10 - Edisi Desember 2013.

Adriyendi, 2011, Metode AHP dalam Sistem Penunjang Keputusan Pemilihan Dosen dengan Menggunakan Perangkat Lunak Expert Choise, Jurnal Sainstek, Vol. III No. 2, ISSN: 2085-8019, Desember 2011, Hal. 136-148.

Asfi Marsani, dkk, 2014, Sistem Penunjang Keputusan Seleksi Mahasis wa Berprestasi Menggunakan Metode AHP (Studi Kasus: STMIK CIC Cirebon), Jurnal Informatika, Vol.6, No.2, Desember 2010: Hal. 131 -144 .

Marimin, Prof. Ir., MSc., 2004, Teknik dan Aplikasi Pengambikan Keputusan Kriteria Majemuk, Grasindo, Jakarta.

Ombuh, Dirk J., 2007, Pemilihan Sistem Penyediaan Air Baku di Pulau Kahakitang, Thesis, Pasca Sarjana Unsrat, Manado.

Pasaribu Eva Solita dan Iskandar, 2015, Sistem Pendukung Keputusan Promosi Jabatan Karyawan dengan Metode Analytical Hierarchy Process (AHP) Study Kasus pada PT. Selular Global Net Medan, Jurnal Teknologi dan Sistem Informasi, Vol.1, No.2, Maret 2015: Hal. 71-78.

Pressman Roger S., 2012, Rekayasa Perangkat Lunak, Buku 1, Pendekatan Praktis, Edisi 7, Edisi Bahasa Indonesia, Penerbit Andi, Yogyakarta.
Saaty Thomas L.,1993, Pengambilan Keputusan Bagi Para Pemimpin, Seri Manajemen No. 134, PPM, Jakarta

Tim Pengembang Portal Resmi UNSRAT, 2015, Pembangunan Portal Resmi Universitas Sam Ratulangi Manado, Laporan Akhir, Manado.

Yahfizham, 2014, Sistem Informasi Berbasis Komputer Sebagai Pendukung Keputusan Pemilihan Pejabat Menggunakan Metode AHP, Jurnal Iqra', Vol.08 No.01, Mei 2014.

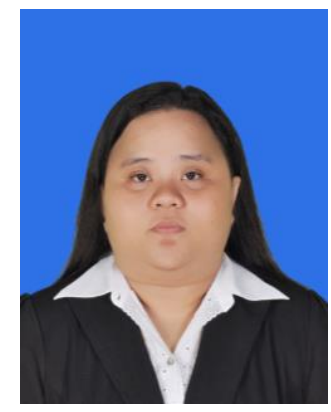

Sekilas dari penulis dengan nama lengkap Martina Karen Ertha Timbubamba Dundu, lahir di kota Manado, Provinsi Sulawesi Utara, Anak ke-2 dari 3 bersaudara. Pendidikan Sekolah Dasar GMIM 6 Manado. Kemudian melanjutkan ke Sekolah Menengah Pertama Katolik Stella Maris Tomohon. Kemudian melanjutkan ke Sekolah Menengah Atas (SMA) Negeri 9 Manado. Setelah lulus SMA tahun 2007 sempat bekerja sebagai tenaga administrasi dan keuangan pada perusahan konstruksi dan perusahan pengekspor ikan di kota Bitung dan tahun 2011 melanjutkan ke Perguruan Tinggi di Universitas Sam Ratulangi Manado dengan mengambil Jurusan Teknik Elektro dengan Program Studi Teknik Informatika. Penulis membuat Skripsi demi memenuhi syarat Sarjana (S1) yang dibimbing oleh dua dosen pembimbing yaitu Dr. Eng Steven R. Sentinuwo, ST., MTI dan Agustinus Jacobus, ST., M.Cs sehingga pada tanggal 29 Juni 2016 penulis dinyatakan lulus melalui sidang sarjana di Teknik Informatika Universitas Sam Ratulangi Manado dan menyandang gelar Sarjana Komputer. 